\title{
Self- and Other-Repairs in Child-Adult Interaction: A Case Study of a Pair of Persian-Speaking Twins
}

\author{
Leily Ziglari ${ }^{1} \&$ Burhan Ozfidan ${ }^{1}$ \\ ${ }^{1}$ Texas A\&M University, USA \\ Correspondence: Leily Ziglari, Texas A\&M University, USA. E-mail: leily.ziglari@tamu.edu
}

Received: March 1, 2016 Accepted: June 27, 2016 Online Published: July 13, 2016

doi:10.5539/ijel.v6n4p52 URL: http://dx.doi.org/10.5539/ijel.v6n4p52

\begin{abstract}
Twenty-five years ago, Schegloff (1989) proposed that repair is the most crucial factor in understanding the nature of language development. By observing and examining the repairs children make, not only can we understand repair organization, but also children language development and cognitive stage. Research in syntactic structure of repair, self-initiated self-repair (SISR) or other-repair have gained enough attention in recent years through the works of Forrester (2008), Radford (2008), and Morgenstern, Leroy, \& Caef (2013). Some studies analyzed both self-repair and other-repair (Morgenstern et al., 2013; Salonen \& Laakso, 2009; Forrester, 2008), whereas a few other studies analyzed only other-repairs from the perspective of parents (Huang, 2011). There are many studies done regarding the incidence of self-repair over other-repair (Schegloff et al., 1977); the relationship between repair and turn (Schegloff, 1988); corrective feedback (Laakso \& Soininen, 2010); other-repetition (Huang, 2011); and adult's self-repair (Laakso \& Sorjonen, 2010). However, there is some inconsistency in their findings. The data for this study comprised four video-recorded adult-child interactions at a children's home in various interactional activities (role-play, short story, or watching cartoons. The purpose of this study is to examine the incidence of self- and other-repairs in the language acquisition process of Persian children and to investigate if there is a relationship between child's self-repair and adult's other-repair.
\end{abstract}

Keywords: self-repair, other-repairs, language development

\section{Introduction}

Schegloff, Jefferson, \& Sacks (1977) defined self-repair as revisions speakers make. Schegloff et al. (1977) claimed: in self-repair, the speaker sees the problem in her prior speech and then she either replaces an element or inserts an element into her proceeding talk. Self-repair is not equal to "error correction", because repair is broader than error correction and it is not limited to the cases in which slip or error has occurred. Rather, self-repair takes into account all instances considered problematic and needed. It has a particular structure with a beginning and ending called "a repair sequence". Schegloff et al. (1977) specified the repair sequence as having 4 stages: "(1) an utterance containing the source of the problem is produced by one of the co-speakers; (2) the problem can be signaled by the speaker (self-initiation) or the co-speaker (other-initiation) who may therefore initiate the repair; (3) the repair is produced by the speaker (self-repair) or by co-speaker (other-repair); (4) the co-speaker can acknowledge the understanding of the repair and the conversation continues" (p. 152).

Other-repair is defined as when the adult explicitly corrects the sentence structure that she thinks the child has not fully mastered (Morgenstern, 2013). In fact, in other-repair, the adult first elicits a specific linguistic element for the child to correct his language. If the child ignores it and doesn't repair his utterance, the adult explicitly offers a repair and corrects his language. Self-repairs are categorized into spontaneous self-repair or elicited self-repair. If the child repairs (corrects) his problematic utterance after being exposed to the adults' repair elicitation through rising intonation or question markers (what?), he can repair his own utterance and it is called elicited self-repair. Conversely if the child understands that his language has a problem and spontaneously corrects his utterance, it is called spontaneous self-repair.

Many research studies have examined the concept of "repair" separately from different perspectives. For instance, some studies have investigated the child's self-repair and adult's other-repair separately, or they focused on repair from different perspectives. Morgenstern et al. (2013) focused on the self- and other-repairs simultaneously according to two frameworks of conversation analysis and language development. They found 
that child's self-repair was preferred over the adult's self-repair. However, there is a difference in their findings with the study of Forrester (2008), who found that self-repair is predominant at all ages. We assume it is due to the fact that they have selected different theoretical frameworks and methodologies. Morgenstern et al. (2013) based their analysis only on the "corrective repair sequences" (p. 164) whereas in the conversational analysis framework (CA) of Forrester (2008), the researcher included much more sequences, and even he used non-lexical repairs in his coding system.

All these studies have described "self-repair" and "other-repair" in the process of adult-child interaction. Among all, Morgenstern et al. (2013) examined the relationship between mother's other-repair versus the child's self-repair that will be the focus of the present study. They found that "mother repairs child's phonology, morphology, and then her lexicon and pragmatic adequacy" (p. 165). This repair transition is accompanied by child's linguistic development. However, this was not the focus of the current study, since the subjects in this study were 3-year-old and had passed the stage of phonological development. Rather, it is aimed to examine the relationship between the amount of self-repair produced by the child and other-repair that is produced by the adult. However, Morgenstern et al. (2013) further examined this kind of relationship and found that similar to the works of Chouinard \& Clark (2003), children used high percentage of other-repair in early language development and they used self-repair later. The decrease of other-repairs parallels the increase of the proportion of the mother's elicitations of self-repairs (p. 164). This transition from other-repair to the self-repair indicates the development of child's cognitive and social development.

Salonen \& Laakso (2009) studied the "self-repair" of 4-year-old Finnish children from another perspective. They didn't look at the repair as an indicator of child's syntactic development, but as a sign of child's pragmatic development. They found that children's self-repair is significant as it tells us more about the children's interactive skills and their social cognition and therefore, self-repair is socially motivated. It is in line with what is said in the introduction paragraph that repair is different from error correction. Salonen \& Laakso (2009) found that except phonological self-repairs, other types of self-repair were not aimed at correcting errors. The child may change his/her utterance to resemble the appropriateness of language. This was a significant study and the results were in contradiction with the studies of McTear (1985, cited in Salonen \& Laakso, 2009) that defined self-repair as correcting only single words while children do not repair other unproblematic utterances.

Forrester \& Cherrington (2009) also examined the relationship between parents' other-repairs with each other. The parents' other-repetition were further classified into the four different types of exact, reduced, modified and expanded repairs. This was a kind of qualitative study and they tried to link "repair" with its "communicative context". Although their studies examined the relationship between repairs, it was limited only to the relationship between parents' "other-repairs" with each other. They excluded the child's self-repair in their study. We assume that repairs are interchangeably related to each other, and in order to get more insight into the nature and functions of repairs, we need to take both self-repair and other-repair into consideration. It is not reasonable to look at only one of them (other-repair) at the expense of another (self-repair). Wooton (2007), however, analyzed repair differently. He examined the use of "please" in both "offer" and "request" sequences and then he briefly talked about "self-repair". He wanted to present how a child employs his skills to say "please" to fulfill different functions in the repair sequence. His results cannot give us an insight into the developmental process of language acquisition since the total number of hours was 6 hours in a case study.

\section{Method}

\subsection{Data Collection}

The data for this study comprised four video-recorded adult-child interactions at a children's home in various interactional activities (role-play, short story, or watching cartoons), a total of 8:30 hours. The children were a pair of twins at the age of 3;0-4;0 year old: One boy and one girl named Fatemeh (FAT) and Mohammad (MOH). Different interactional patterns such as mother-child, researcher-child, child-child and babysitter-child were captured by the camera. From all these recordings, only researcher-children and mother-children interactions were selected for data analysis and were further specified in the domain of repair. Children and adult were all Persian speakers. Furthermore, the children were physically and mentally normal, but due to their parents' job, most of their daily hours were limited to playing with each other or talking to an elderly babysitter. Therefore their vocabulary domain was not highly developed at the beginning of this study.

\subsection{Procedure}

The researcher both observed and interacted with children in their playtime. The play materials included the nursery books, plastic puzzle toys, cartoon DVDs, and role-play. The researcher didn't instruct the children on using a correct form of language. Rather, she used repair strategies or elicitations of self-repair as cited by 
Morgenstern et al. (2013) to elicit the correct response of the children by using one word of child's problematic utterance with rising intonation; asking for clarification; using the problematic word and reformulating into her utterance to offer a model for the child. If the children were tolerant of the other-repair signal, the researcher used the corrected form of that phrase or vocabulary. All the interactions were recorded by the camera hidden from the children's sight. Both other- and self-repairs were analyzed through the framework of language acquisition theory. Among the 4 video-recorded tapes of data collection from the researcher-made corpus, session 2, 4, 16, and 18 were selected for analysis with an interval of one month of recording. Therefore session 2 and 4 are related to the first stage and sessions 16 and 18 are related to the later stage of language acquisition.

\subsection{Coding}

The present Persian data collection (researcher-made corpus) has been already transcribed by BGN transcription system to be systematic in or thography. Also, they had already been transcribed by the standardized rules of Chat available in CHILDES for the data analysis. The framework of language acquisition specialists (Clark \& Chouinard, 2000) was used for the data analysis in terms of repair. The data was not analyzed by the framework of CA as the researcher didn't aim to trace some specific features such as children's pause, coverage or eye gazing for analysis. In the following, it is explained how different terms of repairs have been coded as cited by Clark \& Chouinard in 2000.

The mother (the adult in this study) signals the problem. She can encourage the child to correct herself (ex. no it is not $\mathrm{X}$, it's $\mathrm{Y}$ ); she reformulates child's utterance (ex. she takes up the problematic utterance and reformulates $\mathrm{it}=$ embedded), or she explicitly corrects the child (corrective feedback). It might be the case that adult tolerates the problematic utterance. Therefore adults' other-repair is either explicit or implicit (Clark \& Chouinard, 2000). Child's self-repair can be either spontaneous (ex. corrects her problematic utterance); or elicited by the adult who signals a problem. The instances of elicitation of repair are when adult does not show attention to children's response, or asks for clarification such as what?

\section{Results}

In the current study, we wanted to examine the incidence of different types of repairs children make and then to examine if there is a relationship between children's self-repair and adult's other-repair as the child develops. Some information about the MLU of the children is given in table 1 as a representation of their linguistic development at the onset of the data collection.

Table 1. MLUs of FAT and MOH in the second session of data collection

\begin{tabular}{llllll}
\hline Participant & N. of session & N. of utterance & N. of morphemes & $\begin{array}{l}\text { MLU= ratio of } \\
\text { morphemes/utterance }\end{array}$ & SD \\
\hline FAT & 02 & 46 & 86 & 1.870 & .824 \\
MOH & 02 & 118 & 221 & 1.873 & .962 \\
\hline
\end{tabular}

In order to claim that children's language development were roughly the same at the beginning of the study, their MLU was computed. The mean length values (MLU) and standard deviations for the two subjects are reported in table 1. We excluded the first recording tape from the dataset as the children in the first session were unwilling to talk and remained silent. In the following paragraphs, we have written some examples of adult-child interaction with analysis of both types of repair and structure of the repair sequence. Please notice that MOT=mother; $\mathrm{INV}=$ investigator; FAT $=$ Fatemeh; and $\mathrm{MOH}=$ Mohammad.

(Extract 1: There is a plate of fruit on the table. Fatemeh is only pointing at the fruit and looking at the researcher (Investigator=INV). She utters an incomprehensible word).

*INV: chī shod? /what?/

*FAT: looks at the fruit.

*INV: chīshod? Esmeshchīye? /what? What is the name?/

*FAT: ++++

*INV: Mīveshchīye?/ what is the name of the fruit?/

*FAT: Esmeshmīve.....mīve.....mīvebefarmāyn /the name is fruit; eat fruit/

In this example, Fatemeh didn't know the name of the object (fruit). This lack of knowledge is the first signal for the repair sequence. We recognized this and used repair strategies such as elicitation marks (ex. question? or the 
marker what?) to help Fatemeh produce the language. Fatemeh understands that these markers can help her to produce the language. Then she gets the word "mive" /fruit/ and incorporates it into her language, repairs her utterance and produces the correct form. Here the child replies to the adult's other-repair and repairs her own utterance, and it is a case of elicited self-repair. Consider another extract:

(Extract 2: The researcher wants to play with the kids)

*INV: khobhālā bāzī konīm? /ok' let's play a game/

*FAT: bale. (yes)

*INV: +<chebāzī? /what kind of game?/

* FAT: bāzī +... /game/

*FAT:bāzī +.../game/

At the first utterance, the child only says "yes", but then she uses the word from the researcher's utterance and uses into her own talk (although incomplete). This other-repair example shows that the child gets the input from the adult's talk (adult's other repair) and uses in her production (=repairs), but she cannot complete it since she is not exposed to any other word in this sequence to employ them into her utterance. There are several examples observed in the corpus that the child is talking, but when (s)he is asked to repeat the language, (s)he says /nemīdunam= I don't know/ or /hīchī nagoftam= Isaid nothing/. These examples can indicate that in early sessions of language learning, the child depends on the adult's talk to complete her language, or to repair her language (other-repair or elicited self-repair). Here is another example:

(Extract 3: Interaction between mother-child)

\%com: Fateme goes to ask the time.

*FAT: māmānsā'ate tande [: chande]? /mommy, what/d/ime is it?/

*MOT: sā'at chande? /What time is it?/

*FAT: bale. /yes/

*MOT: sā'at bīstdeyqe be yek. /time is 20 minutes to $1 /$

*FAT: bīstkeyqe [: deyqe] [*] be yek. /20 minutes to $1 /$

*INV: chande\&=smiling? /What time is it?/

*FAT: memīdūnam [: nemīdūnam]. /I don't know/

*INV: namāmāngoftandchande? /Mommy said what time is it?/

*FAT: memīdūnam [: nemīdūnam]. /I don’t know/

*INV: bīstdaqe? /20 minutes?/

*FAT: na. /no/

In this extract, Fatemeh uses her mother's input into her dialog and speech, but she is unable to remember it in the next utterances. It seems that repair does not always lead to permanent learning, and it might have coverage with rote memorization. Therefore, we assume not all repairs lead to learning, but learning is affected by employing repair. The result of these extracts bring more evidence for the fact that adults also used more repetition or other-repair in the early sessions of child's language development than they did in the later sessions. According to Sokolov (1993), it has been argued that the repetition aspect of adult responses is important because it catches the child's attention and he/she can comprehend language and conversation proceeds. Therefore, it can be inferred that if the child doesn't hear enough other-repair in the adult's input, she cannot complete his utterance due to his loss of attention or limited memory, especially in the first sessions of language acquisitions.

One example of the later stage of language development (later sessions) is as follows:

Extract 4:

@ Activity: playing cartoon

*MOH: +<bezā(r) bīyādesh ./bring it!/

MOH: īn (r)ā bezanbīyādesh. /Press this (button) to bring it/

INV: (ignores Mohammad's talk) 
*FAT: $+<<\bar{a} j \overline{1}(\mathrm{r}) \overline{\mathrm{a}}>$ [/] mīkhāmbebīnam. /I wanna see sis/

*INV: $+<$ khāmūsheshmīkonam. /I'm gonna turn it off/

*MOH: mīkhāmājīi (r)ābebīnam./I wanna see the sis/

Compared to Fatemeh, Mohammad was not very talkative. In the above example, Mohammad liked to play with the camera. We ignored him, and we told Fatemeh that we want to switch it off. Mohammad looked at Fatemeh and used those words in Fatemeh's utterance and incorporated them into his own language. This case is an example of child's self-repair. We did not correct him, but lack of our attention was a signal for him to correct his language. There are many examples of child's self-repair in the later sessions of language acquisition.

Extract 5:

@ Activity: playing cartoon

*INV: to ham mīrī bāhāshūnsarekār\&=looking: Mohamad? /do you go to the work with dad?/

*MOH: bale. /yes/

*INV: raftī? /did you/

*MOH: na. /no/

*MOH: ye rūzraftam. /I went one day/

*MOH: chūchūlū [: kūchūlū] būdamraftam. /I went when I was a small (eshmall)/

*INV: ye rūzraftî? /you went one time?/

*MOH: <chūchūlū [: kūchūlū] > [/] raftamūmadam. /when I was a small (eshmall)/

*INV: tā kojā raftī? /where did you go?/

*MOH: chūchūlū [: kūchūlū] būdam.. /when I was a small (eshmall)/

*INV: +< tā zo(h)r būdī? /You were there until noon?/

*MOH: <chūchūlū [: kūchūlū] būdam> [/]. /when I was a small (eshmall)/

*INV: mīge chī \&=looking:fatemeh? /what does he say?/

*MOH: man chūchūlū [: kūchūlū] būdam . /when I was a small (eshmall)/

*MOH: man nīnī būdam. /When I was baby/

*MOH: nīnī chūchūlū [: kūchūlū] būdam./ When I was baby/

In the above example, Mohammad first used repetition to answer our question, but he had a phonological problem in his utterance and the researchers didn't notice what he meant. When we looked at Fatemeh and asked her for clarification, he understood that his language had a problem. Then he self-repaired (ex. paraphrase) to get his message across and said: /when we was a kid, when we was a baby/.

The following is an example of adult's other-repair in this study:

(Extract 6: Fatemeh is addressing Mohammad)

*FAT: cherā nasībdūstnadāre? /why no you likes apple?/

*INV: cherā nasībdūstnadāre? /why no you likes apple?/

*FAT: bale. /yes/

*INV: cherā sībrā dūstnadāre ?/why doesn’t he like an apple?/

FAT: ++

INV: begū cherā sīb (r)ā dūs(t) nadārī. /say: why don't you like an apple?/

*FAT: sīb (r)ācherā dūt [: dūst] nadārī ? /apple why you don’t like?/

In this example, Fatemeh didn't apply the rule of subject-verb agreement (=problematic utterance), and the researchers first repeated Fatemeh's utterance (=signal for problematic utterance) to get her attention that something goes wrong. When she confirmed our utterance, it meant that she didn't notice her error by ourrepetition. Then we reformulated Fatemeh's utterance by offering a model (=other-repair) and she correctly produced it.

(Extract 7: Fatemeh insists the researcher not go home) 
*FAT: naro. /don't leave/

*FAT:man mīkhāmnaro. /I want don't leave/

*INV: to mīkhāynaram? /you want me not to go?/

*FAT: bale. /yes/

In the above example, Fatemeh produced ungrammatical sentence in terms of subjunctive forms and we offered her a correct model (ex. other-repair). In other word, we repaired her utterance in an interrogative construction. Finally, in order to examine if there is a contingent relationship between adults' other-repair and child's self-repair, we used the frequency of the incidence of different types of repairs and represented in the following tables and graphs.

Table 2. The incidence and frequency of different types of repairs

\begin{tabular}{lllllll}
\hline Session & Adult's other-repair & Frequency & Elicited self-repair & Frequency & Spontaneous self-repair & Frequency \\
\hline & & & & & & \\
2 & 9 & 90 & 1 & 10 & 0 & 0 \\
4 & 7 & 46 & 5 & 33 & 3 & 20 \\
16 & 2 & 12.5 & 8 & 50 & 6 & 37.5 \\
18 & 2 & 11.76 & 8 & 47 & 7 & 41.17 \\
\hline
\end{tabular}

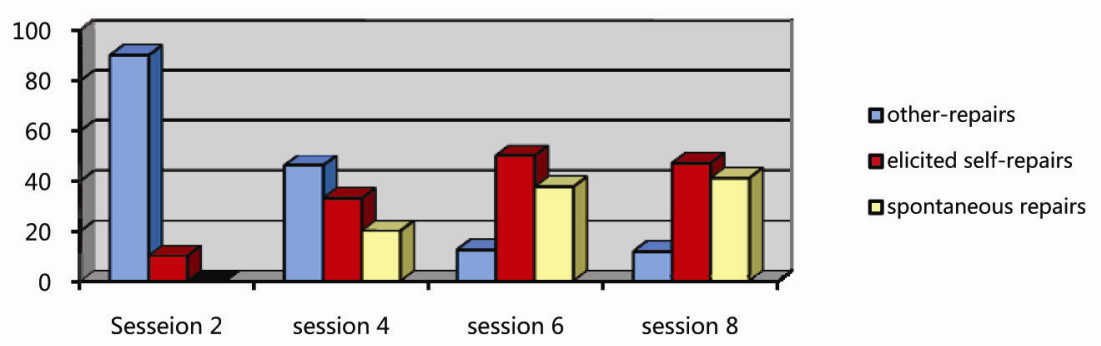

Figure 1. Graphical representation of different types of repairs in adult-child interaction

As it is shown in the above graph, as the other-repair declines with the age of the child, there is more incidence of elicited self-repair and spontaneous self-repair.

\section{Discussion}

The results of this study are in line with the idea of Schneiderman (1984) who found that parents tend to repeat more of their children's ill-formed utterances than well-formed ones. They also discovered that these repetitions often include correction. Furthermore, Gallagher (1981, cited in Clark, 2003) found that with 2-year-olds, adults' most frequent clarification requests were confirmation requests in which adults repeated part or all of the child utterance. This research study did not support the findings of some researchers (Newport, Gleitman, \& Gleitman, 1977; Shatz, Hoff-Ginsberg, \& MacIver, 1989, cited in Clark, 2003) who argued that repetition (in this study other-repair repetitions) is ineffective in the language acquisition.

We conclude that repair may not be sufficient, but they pave the way for the language acquisition to take place. As Vygotsky in his immortal word of ZPD argued, scaffolding is a critical condition in the process of language acquisition. Through using repair strategy, adults can scaffold the child to learn the linguistic system of language in terms of phonology, morphology or syntax. The critical point in the language process through which child passes from the stage of other-repair to the stage self-repair shows a linguistic development.

Self-repair and other-repair are the two crucial indicators of language development. Forrester (2008) mentioned that sound alteration, repetition, conversation monitoring, and orientation to self-positioning are the skills used by child when he wants to repair.

Schegloff (2000) has documented the prevalence of other-repair in adults compared to self-repair in children. However, the results of the study of Morgenstern et al. (2013) opposed the earlier works of Schegloff et al. (2000). The findings of this study were in line with the works of Leroy et al. (2010), who argued that self-repair acts as a signal when children are capable of internalizing rules. Moreover, repairs help us understand the cognitive or linguistic level of the child when they are self-repairing at the particular linguistic level. 
Furthermore, they are important from a socio-interactional theory of language acquisition.

\section{Conclusion}

This study was carried out to examine the incidence of self- and other-repairs in the process of children's language acquisition. The results can lead us to several important findings: children move from a stage of adult's other repair to a stage of self-repair in the LA process and this transition indicates a language/cognitive development. Moreover, contrary to the popular view that holds the children's repetition or imitation are worthless and they represent the lack of language ability of children, we argued that they might be signals that something is happening in the cognitive development of the children. They cognitively pay attention to adult's repair and therefore, the repetition can signal their confirmation or lack of understanding.

The frequency of using other-repair in the early sessions of language development indicates that the children are exposed to the input in the process of language development. Moreover, the analysis of conversational interactions can give us an idea that twins not only learn the language through input addressed to them by adults, but through input they address to each other. It goes without saying that although the innate mechanisms actually play the indistinguishable part in the process of language acquisition, the issue of LA needs to be addressed and reconciled inextricably with the available evidence to the child.

\section{Pedagogical Implications of the Study}

The present study has provided evidence on the role of child's self-repair and adult's other-repair in the process of language acquisition. To begin with, this study has both theoretical and practical implications. The results are beneficial if one incorporates them into language classes in general and child language classes in particular. The kind of feedback, for example, that the teacher produces can affect the students' output and their willingness to communicate. Although using input, corrective feedback, conversational interaction, participation, and natural elicitation methods can be effective and appealing in the process of language development, it might be beneficial if they are carried out in an early age of language acquisition.

The findings have practically some implications to the area of first and second language learning and pedagogy. It is well asserted that the theories of second language acquisition (SLA) have been rooted in first language acquisition (FLA); in other words, the findings in the first language acquisition have a function of a pillar supporting the issues in the second language acquisition and through which some solutions would be provided. In sum, the results of this study can bring out some useful results to be applied broadly by first and second language teachers in their language classes, by parents in their interaction with their children acquiring their first language, and by material writers and developers in designing the syllabus and textbooks.

\section{Significance and Future Research}

Repairs, in general, and self- or other-repair, in particular, are substantial and significant indicators of language development. They are indicators of language development in preschool years and the results of the study in this regard will benefit both the teachers and learners, whether in native-nonnative interactions or adult-child interactions. In this study, it was also manually found that we have used repetition to repair both syntactic and phonological errors of the children. However, we didn't distinguish these two types of errors for the present study. Moreover our elicited repairs were in the form of either repetition or expansion that can be the subject of further research. Also in extract 6, the difference between this example of elicited other-repair and those other-repair examples in the previous studies, is that here Fatemeh not only corrects the language, but also produced it in a new grammatical structure (ex. changing canonical to non-canonical construction). We have become interested in focusing on this novice construction for our further research studies.

\section{References}

Clark, E. V. (2003). First language acquisition. Cambridge: CUP.

Corrin, J. (2010). Maternal repair initiation at MLU Stage I: The developmental power of 'hm?'. First Language, 30(3-4), 312-328. http://dx.doi.org/10.1177/0142723710370526

Forrester, M. A. (2008). The Emergence of self-repair: A case study of one child during the early preschool years. Research on Language and Social Interaction, 41(1), 99-128. http://dx.doi.org/10.1080/08351810701691206

Forrester, M. A., \& Cherington, S. M. (2009). The development of other-related conversational skills: A case study of conversational repair during the early years. First Language, 26(2), 166-191. http://dx.doi.org/10.1177/0142723708094452

Huang, C. C. (2011). Parental other-repetition in Mandarin parent-child interaction. Journal of pragmatics, 43, 
3028-3048. http://dx.doi.org/10.1016/j.pragma.2011.05.014

Laakso, M., \& Soininen, M. (2010). Mother-initiated repair sequences in interactions of 3-year-old children. First Language, 30(3-4), 329-353. http://dx.doi.org/10.1177/0142723710370534

Laakso, M., \& Sorjonen, M. L. (2010). Cut-off or particle-Devices for initiating self-repair in conversation. Journal of Pragmatics, 42, 1151-1172. http://dx.doi.org/10.1016/j.pragma.2009.09.004

MacWhinney, B. (2010). The CHILDES project: Tools for analyzing talk. Retrieved from http://childes.psy.cmu.edu/manuals/chat.pdf

Morgenstem, A., Leroy-Collombel, M. L., \& Caëf, S. (2013). Self- and other-repairs in child-adult interaction at the intersection of pragmatic abilities and language acquisition. Journal of pragmatics, 56, 151-167. http://dx.doi.org/10.1016/j.pragma.2012.06.017

Radford, J. (2008). Practices of other-initiated repair in the classrooms of children with specific speech and language difficulties. Applied Linguistics, 31(1), 25-44. http://dx.doi.org/10.1093/applin/amn046

Salonen, T., \& Laakso, M. (2009). Self-repair of speech by four-year-old Finnish children. Journal of Child Language, 36, 855-882. http://dx.doi.org/10.1017/S0305000908009240

Schegloff, E. A. (2000). When "others" initiate repair. Applied Linguistics, 21(2), 205-243. http://dx.doi.org/10.1093/applin/21.2.205

Schegloff, E. A., Jefferson, G., \& Sacks, H. (1977). The preference of self-correction in the organization of repair in conversation. Language, 53(2), 361-382. http://dx.doi.org/10.1353/lan.1977.0041

Sokolov, J. L. (1993). A local contingency analysis of the fine-tuning hypothesis. Developmental Psychology, 29(6), 1008-1023. http://dx.doi.org/10.1037/0012-1649.29.6.1008

Vygotsky, L. (1978). Mind in society: The development of higher psychological processes. Cambridge: Harvard University Press.

Wooton, A. (1994). Object transfer, inter-subjectivity and third position repair: Early developmental observations of one child. Journal of Child Language, 21, 543-564.

Wooton, J. A. (2007) A puzzle about please: Repair, increments, and related matters in the speech of a young child. Research on Language and Social Interaction, 40(2-3), 171-198. http://dx.doi.org/10.1080/08351810701354623

\section{Copyrights}

Copyright for this article is retained by the author(s), with first publication rights granted to the journal.

This is an open-access article distributed under the terms and conditions of the Creative Commons Attribution license (http://creativecommons.org/licenses/by/3.0/). 